African Crop Science Journal by African Crop Science Society is licensed under a Creative Commons Attribution 3.0 Uganda License. Based on a work at www.ajol.info/ and www.bioline.org.br/cs DOI: https://dx.doi.org/10.4314/acsj.v27i3.12

\title{
AMYLOSE CONTENT AND GRAIN APPEARANCE TRAITS IN RICE GENOTYPES
}

\author{
I.O. KITARA, J.R. LAMO ${ }^{1}$, P. GIBSON and P. RUBAIHAYO
}

College of Agricultural and Environmental Science, Makerere University, P. O. Box 7062, Kampala, Uganda

${ }^{1}$ National Crop Resources Research Institute, P. O. Box 7084, Kampala, Uganda Corresponding author: prubaihayo@gmail.com

(Received 28 May 2018; accepted 9 August 2019)

\begin{abstract}
Amylose content (AC) and grain appearance traits of rice (Oryza sativa L.) represent a major problem of rice marketing in many rice producing areas in the world. In Uganda, cooking, eating and appearance qualities remain undefined in the rice breeding programme. The objective this study was to determine amylose content of rice genotypes, and its relationship with grain appearance traits; and mode of its inheritance in selected rice genotypes. Forty genotypes were planted in two seasons (2015B and 2016A), in alpha lattice design at National Crop Resource Research Institute in Uganda. Seven parents, involving 3 low and 4 intermediate amylose content genotypes selected in 2015B season, were crossed in a half diallel,and the $\mathrm{F} 1$ were advanced to $\mathrm{F}_{2}$ generation, which together with parents were planted in the field. Amylose content (AC), kernel width $(\mathrm{KW})$ and kernel length $(\mathrm{K} / \mathrm{L})$ to width ratio were affected by both genetic effects and genotype by season ( $\mathrm{Gx}$ S) interactions; while kernel length was mainly affected by genetic factors. Genotypes were grouped into low, intermediate and high amylose content categories depending on the environment where the genotypes were grown. Three genotypes (Namche 1, P62H17 and 1190) had no significant responsesin amylose content in different growing seasons, suggesting that these genotypes were stable. Amylose content correlated weakly and negatively with physical appearance quality traits of the grain; implying that improvement in amylose content would not affect grain size and shape.There were significant differences $(\mathrm{P}<0.001)$ among parents for general combining ability (GCA) and among crosses for specific combining ability (SCA) $(\mathrm{P}<0.5)$ for amylose content; indicating that both additive and non-additive gene actions were responsible for the inheritance of AC. However, the variance component of GCA was larger than for the SCA, implying that the inheritance of amylose content was more conditioned by the additive gene effect.
\end{abstract}

Key Words: Combining ability, Oryza sativa, Uganda 
La teneur en amylose (TA) et les caractéristiques d'aspect du grain du riz (Oryza sativa L.) représentent un problème majeur de commercialisation du riz dans de nombreuses régions productrices de riz dans le monde. En Ouganda, les qualités de cuisson, d'alimentation et d'apparence restent indéfinies dans le programme d'amélioration du riz. L'objectif de cette étude était de déterminer la teneur en amylose des génotypes de riz et sa relation avec les caractéristiques d'apparence du grain; et son mode de transmission dans des génotypes de riz sélectionnés. Quarante génotypes ont été plantés au cours de deux saisons (2015B et 2016A), dans la conception de lattice alpha à National Crop Resource Research Institute en Ouganda. Sept parents, impliquant 3 génotypes à faible teneur en amylose et 4 génotypes sélectionnés lors de la saison 2015B, ont été croisés sur un demi-diallèle et les F1 ont été avancés à la génération $\mathrm{F}_{2}$, qui a été plantée avec les parents sur le terrain. La teneur en amylose (TA), la largeur du noyau $(\mathrm{LN})$ et le rapport longueur / longueur du noyau $(\mathrm{K} / \mathrm{L})$ sur la largeur étaient affectés à la fois par les effets génétiques et par les interactions génotype par saison ( $\mathrm{G} \times \mathrm{S})$; tandis que la longueur du noyau était principalement affectée par des facteurs génétiques. Les génotypes ont été regroupés en catégories de teneur faible, intermédiaire et élevée en amylose, en fonction de l'environnement où les génotypes ont été cultivés. Trois génotypes (Namche 1, P62H17 et 1190) n'ont pas eu de réponses significatives concernant la teneur en amylose au cours de différentes saisons de croissance, ce qui suggère que ces génotypes étaient stables. La teneur en amylose était en corrélation faible et négative avec les caractéristiques de qualité de l'apparence physique du grain; ce qui implique que l'amélioration de la teneur en amylose n'affecterait pas la taille et la forme des grains. Il y avait des différences significatives $(\mathrm{p}<0,001)$ entre les parents pour la capacité de combinaison générale $(\mathrm{CCG})$ et entre les croisements pour la capacité de combinaison spécifique $(\mathrm{CCS})(\mathrm{p}<0,5)$ pour la teneur en amylose; indiquant que les actions géniques additives et non additives étaient responsables de la transmission du TA. Cependant, la composante de variance de la CCG était plus importante que celle de la CCS, ce qui implique que la transmission du contenu en amylose était davantage conditionnée par l'effet du gène additif.

Mots Clés: Capacité de combinaison, Oryza sativa, Ouganda

\section{INTRODUCTION}

Uganda has grown lowland rice (Oryza sativa L.) since 1974, especially in Eastern region (MAAIF, 2012). Quality traits in rice comprise of physical appearance, cooking and eating properties; and more recently, nutritional value. The value of each trait, for example, the length of the grain, varies according to local ethnic background of the consumer (Efferson, 1985). Physical properties, including yield of edible and marketable polished grain, uniform shape, whiteness, and in most countries, translucence are immediately obvious to consumers and so they are major factors defining market value of rice (Graham, 2002).

Predictable expression of these traits across seasons and years gives a variety its reputation.
Cooking and eating qualities of rice are mostly determined by amylose content, gel consistency and gelatinisation temperature of the grain endosperm. The appearance quality is determined by grain shape, as specified by length-width ratio and the translucency of the endosperm (Tan et al., 2000). The long-grain quality varieties tend to produce dry, fluffy and separated cooked grains; whereas the mediumand short-grain varieties tend to produce clumped, moist and chewy grains after cooking.

Rice of low amylose content are waxy, sticky and do not expand in volume when cooked; while that of intermediate amylose content $(<30 \%)$ cook moist, tender and does not harden after cooling (Lee, 1987). The high amylose content variety $(>30 \%)$ has high 
expansion volume and is non-sticky but becomes hard on cooling (Rashmi, 2000).

Appearance quality of the rice grain represents a major problem of rice production in many rice-producing areas of the world; and this is especially the case in Uganda (Candia et al., 2013). Currently, there is a strong emphasis in Uganda on improving yield and quality of rice varieties (Lamo et al., 2017). The most serious problems lie in cooking, eating and appearance qualities; and to some extent, in milling quality. Amylose content and grain appearance qualities are highly variable and are greatly influence by variety and environment (Bao et al., 2004). It is prudent to breed for varieties stable in cooking, eating and appearance qualities under local environments; and to establish the mode of the inheritance of amylose content in the local cultivars. The objective of the study was, therefore, to determine the amylose content of selected genotypes, established the inheritance patterns and relationships between grain appearance and amylose content.

\section{MATERIALS AND METHODS}

Forty rice genotypes (Oryza sativa L.), collected from the National Crop Resources Research Institute (NaCRRI) rice breeding programme in Uganda, the International Rice Research Institute (IRRI), the International Institute of Tropical Agriculture (IITA), the Africa Rice Centre (ARC), the International Centre for Tropical Agriculture (CIAT), Madagascar and Korea (Table 1) were planted in the field in alpha lattice design with three replications, in two seasons (2015B and 2016A).

After harvest, the grains were sun-dried to a moisture content of about $14 \%$, and dehulled using porcelain mortar and pestle. Seven lines were selected from the 40 genotypes after characterisation based on the amylose content; and planted in pots in a screen house. They were crossed in a half diallel mating design to generate $\mathrm{F}_{1}$ seed at NaCRRI. Crossing was done by hand pollination, using the manual emasculation and hooking method (Peter et al., 1964). The $F_{1}$ seeds were also planted in pots in the screen house. The produced $\mathrm{F}_{2}$ seeds and their parents were planted in the field in alpha lattice design with three replications, 8 blocks x 5 genotypes, at spacing of $20 \mathrm{~cm} \mathrm{x}$ $20 \mathrm{~cm}$. The $\mathrm{F}_{2}$ plants were harvested individually at maturity and sun-dried until the moisture content was about $14 \%$; before milled using a porcelain mortar and pestle, to produce brown rice.

Amylose content. Amylose content (AC) was determined from the starch, according to the simplified method of Juliano (1971), as modified by Lanceraset al. (2000). Test tubes were used instead of volumetric flasks. A hundred miligrames of rice starch was put into a test tube and was wetted with $1 \mathrm{ml}$ of $95 \%$ ethanol and $4.6 \mathrm{ml}$ of $1 \mathrm{M}$ sodium hydroxide. The contents were hand shaken for 30 seconds and then heated in a boiling water bath for 10 minutes to gelatinise the starch.

After cooling for 30 minutes on the bench, the volume of the solution was made up to 10 $\mathrm{ml}$ using distilled water. A tenth of the sample was pipetted from the $10 \mathrm{ml}$ into test tube in duplicates. One milliliter $1 \mathrm{M}$ acetic acid and $2.0 \mathrm{ml}$ I-KI solution were added to each test tube; and the volume in the test tubes made up to $8.25 \mathrm{ml}$ with distilled water. The absorbance of the solution was measured at $620 \mathrm{~nm}$ against the blank solution, using a spectrophotometer (UNICAM UV300, Thermo scientific, UK). AC was calculated using a standard curve made from pure amylose starch from Sigma A0512.

Appearance traits. The grain dimensions were measured according to the method described by Kanchana et al. (2012). Rice was de-husked using porcelain mortar and pestle. Ten randomly selected unbroken, brown rice grains of each genotype were lined up lengthwise along the $\mathrm{x}$-axis of a graph paper to measure the length, before the grains were 
TABLE 1. Rice genotypes used in the study of amylose content and rice grain appearance traits

\begin{tabular}{|c|c|c|}
\hline Genotype & Category & Source \\
\hline 1189 & Irrigated & Africa rice \\
\hline 1190 & Irrigated & Africa rice \\
\hline 1191 & Irrigated & Africa rice \\
\hline Nerica 4 & Upland & Africa rice \\
\hline Nerica 6 & $\mathrm{RL}$ & Africa rice \\
\hline TXD306 & Irrigated & Tanzania \\
\hline Jaribu & Irrigated & Tanzania \\
\hline ART10-1L15P1-4-8-1 & Upland & Africa Rice \\
\hline ART3-8L6P3-2-2-B & Upland & Africa Rice \\
\hline WAB 788-16-1-1-2-HB & Upland & Africa Rice \\
\hline ART 3-8L6P3-2-3-B & Upland & Africa Rice \\
\hline ART16-5-4-3-3-1-1-1 & Upland & Africa Rice \\
\hline ART 3-7L3P3-B-B-2 & Upland & Africa Rice \\
\hline ART 16-4-11-13-4 & Upland & Africa Rice \\
\hline GSR-1-0057 & Irrigated & IRRI \\
\hline ART 3-2L4P19-2-1-B & Upland & Africa Rice \\
\hline Namche 1 & Upland & NaCRRI \\
\hline Namche 2 & Upland & NaCRRI \\
\hline Namche 3 & Upland & NaCRRI \\
\hline Namche 5 & Upland & NaCRRI \\
\hline $\mathrm{P} 23 \mathrm{H} 1$ & Upland & NaCRRI \\
\hline Scrid 037-4-2-2-5 & Upland & NaCRRI \\
\hline $\mathrm{P} 26 \mathrm{H} 1$ & Upland & NaCRRI \\
\hline P5H6 & Upland & NaCRRI \\
\hline P5H14 & Upland & NaCRRI \\
\hline $\mathrm{P} 24 \mathrm{H} 10$ & Upland & NaCRRI \\
\hline P29H1 & Upland & NaCRRI \\
\hline $\mathrm{P} 24 \mathrm{H} 1$ & Upland & NaCRRI \\
\hline P5H12 & Upland & NaCRRI \\
\hline $\mathrm{P} 27 \mathrm{H} 3$ & Upland & NaCRRI \\
\hline P62H17 & Uplnd & NaCRRI \\
\hline Scrid 006-2-4-3-5 & Upland & Madagascar \\
\hline 326104 & $\mathrm{RU}$ & Korea \\
\hline Suparica & Upland & IITA \\
\hline Scrid 006-2-4-3-4-5 & Upland & Madagascar \\
\hline РCТ-4\0\0\0>19-M-1-1-5-1-M & Upland & CIAT \\
\hline $\mathrm{P} 24 \mathrm{H} 11$ & Upland & CIAT \\
\hline Scrid 037-4-2-2-5 & Upland & Madagascar \\
\hline 1052 supa line & Upland & IRRI \\
\hline Suparica & Upland & AfricaRice \\
\hline
\end{tabular}

RLL = Rainfed Lowland, NaCRRI = National Crop Resource Research Institute, IRRI = International Rice Research Institute 
arranged in the breadth to measure the width. The values were averaged and used as measurements for length and width of individual grains. The length to width ratio of the grains was calculated, and these results which reflected the shape of the grains recorded(Graham, 2002).

Statistical analysis. Data were analysed per season and combined across seasons, using the linear mixed model (REML) option of GenStat $12^{\text {th }}$ Edition (VSN International Ltd., UK). Genotypes were considered as fixed effects; while seasons, replications and blocks within replications as random effects. The statistical procedures followed a statistical model of lattice incomplete block analysis, with adjusted blocks within unadjusted replications following equation suggested by Dabholkar (1992):

$Y i j k=\bar{Y} \ldots+$ Gi $+R j+(B / R+e i j k$

Where:

Yijk = observation of genotype in replication $j$, and block $k ; \bar{Y}=$ the general mean; $G i=$ effect of genotype $i$; R $j=$ effect of replication $j$ and $(\mathrm{B} / \mathrm{R}) i j=$ the interaction effect between replication $j$ and block $k$; and eijk = error of observation ijk.

After analysing for season one and two, a combined season analysis was performed following the model:

$Y_{i j k}=\bar{Y}+G i+S j+G x S i j+S / R j k+e i j k$

Where:

$\overline{\mathrm{Y}}$ is grand the mean; $\mathrm{Gi}$ is the effect of the $\mathrm{i}^{\mathrm{th}}$ genotype; $\mathrm{Sj}$ is the effect of the $\mathrm{j}^{\text {th }}$ season; $\mathrm{GxS}_{\mathrm{ijis}}$ the interaction of the $\mathrm{i}^{\text {th }}$ genotype with the $j^{\text {th }}$ season; $\mathrm{S} / \mathrm{R}_{j k}$ is the effect of the $k^{\text {th }}$ replication in the $\mathrm{j}$ season; and $\mathrm{e}_{\mathrm{ijk}}$ is the random error.

For the analysis of combining ability and gene action, in relation to half diallel mating design, Alpha lattice design consisting of 3 replications, 8 blocks and five plots was used. In each block, each plot contained $15 \mathrm{~F}_{2}$ plants. The genotypic difference among $\mathrm{F}_{2}$ plants was tested by $\mathrm{F}$ test as suggested by Dabholkar (1992)

$\mathrm{F}[(\mathrm{a}-1), \mathrm{m})]=\mathrm{MSg}, / \mathrm{MSe}$

Where:

$(a-I)$ and $m$ are the degrees of freedom associated with the numerator and denominator of the F ratio; and $\mathrm{MSg}$ and $\mathrm{MSe}$ are the genotype and error mean squares, respectively.

Combining ability was analysed following Method 4 Model 1 of Grifing (1956) option of GenStat (VSN International Ltd., UK) following the model:

$Y i j=\bar{Y} \ldots+G i+G j+S i j+B k+e i j k$,

Where:

$\overline{\mathrm{Y}}$ is the general mean; Giis the general combining ability effect of $i^{\text {th }}$ parent; $G j$ is the GCA effects of $j^{\text {th }}$ parent; Sij is the SCA of $i j^{\text {th }}$ cross; $\mathrm{Bk}$ is the effect of kth block and eijk is the error effect particular to the $i j k^{\text {th }}$ observation.

The mean square error was used as denominator in the F-values for testing combining abilities (Grifing, 1956) as:

$\mathrm{F}[(\mathrm{p}-1), \mathrm{ml}=\mathrm{Mg} / \mathrm{Me}, \mathrm{F}[p(p-3) / 2, \mathrm{ml}=\mathrm{Ms} /$ $\mathrm{Me}$

Where:

$\mathrm{Mg}$, Ms and Me are mean square due to GCA; SCA and error, respectively. [(p-1),m] and $[\mathrm{p}(\mathrm{p}-3) / 2, \mathrm{~m}]$ are degrees of freedom associated with the numerator and denominator of the $\mathrm{F}$ ratio, respectively.

Component due to GCA and SCA was calculated according to Singh and Chaudhary (2007).Error $\left(\delta^{2} \mathrm{e}\right)$, genotypic $\left(\delta^{2} \mathrm{~g}\right)$ and phenotypic $\left(\delta^{2} \mathrm{p}\right)$ variances were calculated from expected mean squares of analysis of 
variance according to Grifing (1956). Under the assumptions that parents were unrelated, negligible epistasis and negligible maternal effects, additive $\left(\sigma_{\mathrm{a}}^{2}\right)$ and dominance $\left(\sigma_{\mathrm{d}}^{2}\right)$ genetic variances can be related to GCA and SCA effects as follows:

$\sigma_{\mathrm{a}}^{2}=4 \sigma^{2} \mathrm{GCA}$

$\sigma_{\mathrm{d}}^{2}=4 \sigma^{2} \mathrm{SCA}$

$\sigma^{2} \mathrm{P}=2 \sigma^{2} \mathrm{GCA}+\sigma^{2} \mathrm{SCA}+\sigma^{2} \mathrm{e}$

Heritability was estimated according to the relationship between additive $\left(\sigma a^{2}\right)$, genotypic $\left(\sigma^{2} \mathrm{~g}\right)$ and phenotypic $\left(\sigma^{2} \mathrm{p}\right)$ variance. Broad sense heritability $\left(\mathrm{H}^{2}\right)$ was determined as the ratio of genetic variance to phenotypic variance; and narrow sense heritability $\left(h^{2}\right)$ was determined as the ratio of additive to phenotypic variance. Baker's ratio was used to determine the progeny performance based on the relative importance of GCA and SCA mean squares, according to fixed effects model 1 (Baker, 1978).

\section{RESULTS AND DISCUSSION}

The results of analysis of variance for amylose content in seasons 2025B, 2016A and across seasons are presented in Table 2. There was a strong genotype effect $(\mathrm{P}<0.01)$ for amylase content and season-by-genotype interactions $(\mathrm{P}<0.5)$ for the amylase content of the genotypes (Table 2), indicating the importance of genotype and environment in the control of the trait. Grain appearance traits (L/W, KL and $\mathrm{KW}$ ) were affected by the genotype, and to a less extent by season (Table 3 ). In the case of kernel length, the season and season by genotype interaction had no significant $(\mathrm{P}>0.05)$ influence.

Rice genotype grown in 2015B had consistently higher AC than the same genotype grown in 2016A (Table 3). The results also indicate that the extent of the decrease in AC was cultivar-dependent, suggesting that some cultivars, for example 1190 and P62H17, were more stable than others for example, ART38L6P3-2-3-B. However, in this study the temperature was much lower in seasons $2015 \mathrm{~B}$ $\left(24 / 20^{\circ} \mathrm{C}\right.$ day/night) than in season $2016 \mathrm{~A}(30 /$ $20{ }^{\circ} \mathrm{C}$ day/night), especially during the grain filling period, suggesting that the high day temperature was the cause of decrease in amylase content of genotypes in the 2016A season. Resurrection et al. (1977) noted that $\mathrm{AC}$ in rice decreased as the mean temperature increased and that the greatest drop in amylose content due to increase in day temperature. In contrast, genotype P24H10, ART3-8L6P3-23-B-C and ART3-8L6P3-2-3-B had higher AC in season 2016A than in 2015B. Similar results were reported by Champagne et al.(2004), who noted high amylose content, in two waxy cultivars in year 2 , which was hotter than year 1. Zheng-xun et al. (2005) reported that the extent of increase or decrease in AC

TABLE 2. Analysis of variance for amylase and grain appearance traits of rice genotype at the National Crop Resources Research Institute (NaCRRI) in Uganda

\begin{tabular}{lccllll}
\hline AOV & Df & AC\% & GW & L/W & KL & KW \\
\hline Seson & 1 & $349.73^{* *}$ & $0.40^{*}$ & $1.83^{*}$ & $0.03 \mathrm{~ns}$ & $0.94^{*}$ \\
Genotype & 39 & $49.30^{* *}$ & $0.14^{* *}$ & $0.38^{* *}$ & $0.48^{* *}$ & $0.28^{* *}$ \\
Season/genotype & 38 & $5.24^{* *}$ & $0.03^{* *}$ & $0.11^{*}$ & $0.12 \mathrm{~ns}$ & $0.09^{*}$ \\
Error & 91 & 1.83 & 0.02 & 0.11 & 0.18 & 0.10 \\
Lee & 81 & & 0.01 & 0.07 & 0.11 & 0.06 \\
\hline
\end{tabular}

$\mathrm{AC} \%=$ Amylose content percent, $\mathrm{Gw}=$ grain weight, $\mathrm{L} / \mathrm{W}=$ kernel length to width ratio, $\mathrm{Kl}=$ kernel length, $\mathrm{Kw}=$ kernel width, $*$ and $* *$ significant difference at $\mathrm{P}<0.05$ and $\mathrm{P}<0.01$, respectively 
TABLE 3. Amylose content of rice genotype grown at the National Crop Resources Research Institute (NaCRRI) in Uganda

\begin{tabular}{|c|c|c|c|c|}
\hline \multirow[t]{2}{*}{ Origin } & \multirow[t]{2}{*}{ Genotype } & \multicolumn{3}{|c|}{ Amylose content } \\
\hline & & 2015B & $2016 \mathrm{~A}$ & $\begin{array}{l}\text { Across } \\
\text { seasons }\end{array}$ \\
\hline \multirow[t]{17}{*}{ Africa Rice } & 1190 & 27.65 & 27.99 & 27.86 \\
\hline & 1191 & 19.93 & 18.52 & 19.12 \\
\hline & ART10-1L15P1-4-8-1 & 23.4 & 22.16 & 22.63 \\
\hline & ART12-L4P7-21-4-B-3 & 26.04 & 19.20 & 20.91 \\
\hline & ART15-11-8-5-2-B-1 & 26.79 & 20.13 & 23.46 \\
\hline & ART16-4-11-13-4 & 17.82 & 16.11 & 16.97 \\
\hline & ART16-5-4-3-3-1-1-1 & 16.22 & 14.54 & 15.38 \\
\hline & ART25-3-29-2-B & 22.26 & 16.76 & 19.51 \\
\hline & ART3-2L4P19-2-1-B & 23.21 & 17.00 & 20.10 \\
\hline & ART3-7L9P8-3-B-B-2 & 24.69 & 22.63 & 22.71 \\
\hline & ART3-8L6P3-2-3-B & 27.55 & 21.44 & 24.76 \\
\hline & GSR-1-0057 & 23.59 & 20.69 & 22.14 \\
\hline & Jaribu 220 & 22.5 & 19.55 & 21.03 \\
\hline & Nerica 4 & 22.5 & 21.39 & 21.94 \\
\hline & Nerica 6 & 24.21 & 21.68 & 22.94 \\
\hline & TXD306 & 22.74 & 18.22 & 20.03 \\
\hline & WAB788-16-1-1-2-HB & 22.17 & 20.76 & 21.46 \\
\hline CIAT & CT11891-3-3-3-M-1-2-1-M & 17.57 & 16.09 & 16.68 \\
\hline CIAT & $\mathrm{PAC}-4 / 0 / 0 / 0>19-\mathrm{M}-1-1-5-1-\mathrm{M}$ & 23.42 & 19.54 & 21.48 \\
\hline IRRI & 1052 & 16.75 & 18.79 & 17.76 \\
\hline Korea & 326104 & 22.51 & 20.45 & 21.28 \\
\hline Madagascar & Scrid006-2-4-3-4-5 & 19.82 & 18.72 & 19.51 \\
\hline Madagascar & Scrid 006-2-4-3-5 & 20.68 & 15.86 & 17.45 \\
\hline \multirow[t]{2}{*}{ Madagascar } & Scrid037-4-2-2-5 & 15.5 & 14.85 & 15.11 \\
\hline & Namche 1 & 22.00 & 21.66 & 21.84 \\
\hline \multirow[t]{14}{*}{ NaCRRI } & Namche 2 & 18.16 & 15.33 & 16.74 \\
\hline & Namche 3 & 15.01 & 14.28 & 14.64 \\
\hline & Namche 5 & 23.17 & 22.38 & 22.77 \\
\hline & $\mathrm{P} 24 \mathrm{H} 1$ & 21.33 & 14.3 & 14.81 \\
\hline & $\mathrm{P} 24 \mathrm{H} 10$ & 16.51 & 20.64 & 23.04 \\
\hline & P24H11 & 25.43 & 18.91 & 20.12 \\
\hline & P26H1 & 16.12 & 14.75 & 15.3 \\
\hline & P27H3 & 23.26 & 20.5 & 21.57 \\
\hline & P29H1 & 19.63 & 16.93 & 18.28 \\
\hline & P5H14 & 20.73 & 18.54 & 19.42 \\
\hline & P5H6 & 17.28 & 15.42 & 16.13 \\
\hline & Р62H17 & 20.96 & 20.78 & 20.86 \\
\hline & LSD & 2.83 & 2.19 & 2.54 \\
\hline & CV\% & 6.94 & 6.97 & 10.65 \\
\hline
\end{tabular}

LSD = Least Significant Different, CV = coefficient of variation, 2015B = season one and 2016A season two 
$\%$ varied with varieties. Yamakawa et al. (2007) also reported that $\mathrm{AC}$ of genotype grown in hot environments were lower compared to $\mathrm{AC}$ of same genotypes in low temperature and environments.

There were eighteen genotypes classified with low AC, twenty with intermediate one with high AC in both seasons (Table 4). Again, the results suggested that classification of genotypes, varied from one season to another. Panle et al. (1977) reported that the classification of amylose content into high, intermediated or low depended on the environment where the rice cultivars were grown.

Results for correlation coefficients $(r)$ among the various traits are shown in Table 5. Amylose content weakly correlated and negatively ( $r=-0.003$ to -0.178$)$ with all the studied grain appearance quality traits, implying that breeding for improving the level of amylose content could be achieved without significant change in the quality attributes of the grain characteristics; but it would not be possible to select for amylose content based on the grain appearance of the genotypes. KL correlated significantly and positively with $\mathrm{GW}$ $(\mathrm{r}=0.304)$ but negatively $(\mathrm{P}<001)$ with $\mathrm{L} / \mathrm{W}$ ratio $(\mathrm{r}=-0.483)$.

Fasahat et al. (2014) reported a positive (r $=0.018$ ), but none significant correlation between amylose content and kernel length, while Koutroubasa et al. (2004), reported that AC correlated significantly and positively with KL; and negatively with KW. Roy et al. (2012) reported that $\mathrm{AC}$ exhibited significant positive association with L/W and GW, but Singh et al. (2005) reported that AC correlated positively, but non significantly with $\mathrm{L} / \mathrm{W}$ ratio.

In this study, L/W ratio correlated significantly and negatively $(\mathrm{r}=-0.48)$ with $100 \mathrm{GW}$ and positively $(\mathrm{r}=-58)$ with KL ratio, suggesting that selection for slender grain would reduce GW. Similar results were reported by Vijay Kumar (2015), who asserted that kernel length was negatively correlated with kernel width.
The results of estimated GCA effects for amylose content are presented in Table 6 . The GCA effects were significant for all parents. Suparica, Namche 2, Namche 3 and 1052 showed negative GCA effects; whereas 326104, Namche 1, and NERICA 4 showed positive GCA effects. Desirable parents are those with significant GCA effects in the right direction for the trait of interest (Singh and Chaudhary, 2007). Parents with a significant negative value would contribute toward low value of amylose content, whereas parents with a significant positive value, would contribute towards high value of amylose content (Sharifi et al., 2009). In this regard, Parent 326104 was the best general combiner for high amylose value; and Supaica the best general combiner for reduced amylose content.

The results of estimates of specific combining ability (SCA) are presented in Table 7. Out of the 21 crosses, 13 crosses were good specific combiners for amylose content. Six of the 13 crosses (1052 x Suparica, 326104 $x$ NERICA 4, 1052 x Namche 2, Namche $2 x$ Namche 3, Namch $1 \times$ Nerica 4and Namche $3 \times$ NERICA 4) showed significant $(\mathrm{P}<0.05)$ negative SCA effects, indicating reduced $\mathrm{AC} \%$ in the progenies of the crosses. These results were similar to those obtained by Sharifi et al. (2009), who studied genetic effects for appearance of quality of rice. Seven of the crosses showed positive significant SCA effects for amylose content; indicating increase in the $\mathrm{AC} \%$ of the progenies in these crosses. Similar results were reported by Kuo et al. (1996), who worked with molled rice in China. The superior combination, which revealed a significant value for low amylose content, was 1052 x Suparica; while the cross 1052 x NERICA 4 revealed a significant value for high amylose content, indicating that such combinations would yield desirable segregants useful for development of improved genotype depending on the desired product. The results of the analysis of variance for amylose content from the $\mathrm{F}_{2}$ generation are presented in Table 8 . The result indicated significant differences 
TABLE 4. Classification of genotypes into Khush et al. (1979) AC categories

\begin{tabular}{|c|c|c|c|}
\hline Category & Genotype & Origin & $\mathrm{AC} \%$ \\
\hline \multirow[t]{19}{*}{ Low $(10-20 \%)$} & Namche 3 & NaCRRI & 14.64 \\
\hline & P24H1 & NaCRRI & 14.81 \\
\hline & SCRID037-4-2-2-5 & Madagascar & 15.11 \\
\hline & P26H1 & NaCRRI & 15.30 \\
\hline & ART16-5-4-3-3-1-1-1 & Africa Rice & 15.38 \\
\hline & P5 H6 & NaCRRI & 16.13 \\
\hline & CT11891-3-3-3-M-1-2-1-M & CIAT & 16.68 \\
\hline & Namche 2 & NaCRRI & 16.74 \\
\hline & ART16-4-11-13-4 & Africa Rice & 16.97 \\
\hline & ART3-8L6P3-2-2-B & Africa Rice & 17.05 \\
\hline & Scrid006-2-4-3-4-5 & Madagascar & 17.45 \\
\hline & 1052 & IRRI & 17.76 \\
\hline & P29H1 & NaCRRI & 18.28 \\
\hline & P5 H12 & NaCRRI & 19.09 \\
\hline & 1191 & Korea & 19.12 \\
\hline & ART25-3-29-2-B & Africa Rice & 19.51 \\
\hline & SCRID006-2-4-3-5 & Madagascar & 19.51 \\
\hline & TXD 306 & Africa Rice & 20.03 \\
\hline & ART3-2L4P19-2-1-B & Africa Rice & 20.10 \\
\hline \multirow[t]{17}{*}{ Intermediate (20-25\%) } & P62 H17 & NaCRRI & 20.86 \\
\hline & ART12-L4P7-21-4-B-3 & Africa Rice & 20.91 \\
\hline & Jaribu 220 & Africa Rice & 21.03 \\
\hline & 326104 & Africa Rice & 21.28 \\
\hline & WAB788-16-1-1-2-HB & Africa Rice & 21.46 \\
\hline & PCT-4\0\0\0>19-M-1-1-5-1-M & CIAT & 21.48 \\
\hline & $\mathrm{P} 27 \mathrm{H} 3$ & NaCRRI & 21.57 \\
\hline & Namche 1 & Africa Rice & 21.84 \\
\hline & Nerica 4 & Africa Rice & 21.94 \\
\hline & GSR-I-0057 & Africa Rice & 22.14 \\
\hline & ART10-1L15P1-4-8-1 & Africa Rice & 22.63 \\
\hline & ART3-7L9P8-3-B-B-2 & Africa Rice & 22.71 \\
\hline & Namche 5 & NaCRRI & 22.77 \\
\hline & Nerica 6 & Africa Rice & 22.94 \\
\hline & P24H10 & NaCRRI & 23.04 \\
\hline & ART15-11-8-5-2-B-1 & Africa Rice & 23.46 \\
\hline & ART3-8L6P3-2-3-B & Africa Rice & 24.76 \\
\hline \multirow[t]{3}{*}{ High $(25-30 \%)$} & 1190 & Africa Rice & 27.86 \\
\hline & LSD & & 2.54 \\
\hline & $\mathrm{CV} \%$ & & 10.65 \\
\hline
\end{tabular}

LSD $=$ Least Significant Difference, and CV\% = Coefficient of variation 
TABLE 5. Pearson Correlation Coefficients among grain appearance quality traits and amylose content in rice genotypes in Uganda

\begin{tabular}{llllll}
\hline & $\mathrm{AC} \%$ & $\mathrm{GW}$ & $\mathrm{KL}$ & $\mathrm{L} / \mathrm{K}$ & $\mathrm{KW}$ \\
\hline $\mathrm{AC} \%$ & 1 & & & & \\
$\mathrm{GW}$ & $-0.175 \mathrm{~ns}$ & 1 & & & \\
KL & $-0.178 \mathrm{~ns}$ & $0.304^{*}$ & 1 & & \\
L/W & $-0.003 \mathrm{~ns}$ & $-0.483^{* *}$ & $0.579 * * *$ & 1 & 1 \\
KW & $-0.028 \mathrm{~ns}$ & $0.715^{* * *}$ & $-0.233 \mathrm{~ns}$ & $-0.899^{* * *}$ & 1 \\
\hline
\end{tabular}

$\mathrm{AC} \%=$ amylose content, $\mathrm{GW}=$ grain weight, $\mathrm{KL}=$ kernel length, $\mathrm{L} / \mathrm{W}=$ kernel length to kernel width ratio and $\mathrm{KW}=$ kernel width $*, * *, * * *$, significant at $.05,01$ and .001 , respectively

TABLE 6. Estimates of GCA effects for amylose content of parents involved in $7 \times 7$ half diallel cross

\begin{tabular}{lcc}
\hline Parents & Parental mean & GCA effect \\
\hline 1052 & 17.76 & $-0.96^{*}$ \\
326104 & 21.28 & $1.58^{* *}$ \\
Namche1 & 21.33 & $0.70^{*}$ \\
Namche2 & 16.74 & $-1.06^{*}$ \\
Namche3 & 14.64 & $-0.53^{*}$ \\
Nerica4 & 21.94 & $0.58^{*}$ \\
Suparica & 18.63 & $-1.26^{* *}$ \\
\hline
\end{tabular}

GCA $=$ general combining ability, $* * *=$ significant at $\mathrm{P}<0.05$, and $\mathrm{P}<0.01$ and probability levels, respectively

TABLE 7. Estimate of SCA effects for amylose content in $\mathrm{F}_{2}$ generations of $7 \mathrm{x} 7$ half diallel cross

\begin{tabular}{|c|c|c|c|c|c|c|c|}
\hline Parent & 1052 & 326104 & Nam 1 & Nam 2 & Nam 3 & Nerica 4 & Suparica \\
\hline 1052 & & $1.012 \mathrm{~ns}$ & $0.334 *$ & $-1.014^{*}$ & $0.148 n s$ & $1.36^{*}$ & $-1.84 * *$ \\
\hline 326104 & & & $0.574 *$ & $0.324 \mathrm{~ns}$ & $0.078 \mathrm{~ns}$ & $-1.21^{*}$ & $-0.13 n s$ \\
\hline Nam 1 & & & & $0.568^{*}$ & $-0.95^{*}$ & $-0.768 *$ & $0.242 \mathrm{~ns}$ \\
\hline Nam 2 & & & & & $-0.182 \mathrm{~ns}$ & $0.534 *$ & $0.054 \mathrm{~ns}$ \\
\hline Nam 3 & & & & & & $-0.524 *$ & $1.066^{*}$ \\
\hline Nerica 4 & & & & & & & $0.608^{*}$ \\
\hline Suparica & & & & & & & \\
\hline
\end{tabular}

*,** and are significance different at $\mathrm{P}<0.05, \mathrm{P}<0.01$ probability levels, respectively, and $\mathrm{ns}=$ non significant 
TABLE 8. Mean squares from the analysis of variance of amylose content in $\mathrm{F}_{2}$ populations from $7 \mathrm{x}$ 7 half diallel of different genotypes

\begin{tabular}{|c|c|c|}
\hline Source & d.f. & $\mathrm{AC} \%$ \\
\hline GCA & 6 & $5.91 * * *$ \\
\hline GCA & 6 & $5.91 * * *$ \\
\hline SCA & 14 & $0.95^{*}$ \\
\hline Total & 20 & 2.44 \\
\hline Residual & 40 & 0.44 \\
\hline VCGCA additive component $\left(\delta_{\mathrm{GCA}}^{2}\right)$ & & 7.29 \\
\hline VCSCA dominant component $\left(\delta_{\text {SCAj }}^{2}\right)$ & & 0.51 \\
\hline${ }^{\mathrm{a}} \mathrm{BR}=\left(2 \delta_{\text {gcai }}^{2}\right) /\left(2 \delta_{\text {gcai }}^{2}+\delta_{\text {scaj }}^{2}\right)$ & & 0.94 \\
\hline${ }^{\mathrm{b}} \mathrm{BSH}=\left(2 \sigma^{2} \mathrm{gca}+\sigma^{2} \mathrm{sca}\right) /\left(2 \sigma^{2} \mathrm{gca}+\sigma^{2} \mathrm{sca}+\sigma^{2} \mathrm{e}\right)$ & & 0.96 \\
\hline${ }^{\mathrm{c}} \mathrm{NSH}=\left(2 \sigma^{2} \mathrm{gca}\right) /\left(2 \sigma^{2} \mathrm{gca}+\sigma^{2} \mathrm{sca}+\sigma^{2} \mathrm{e}\right)$ & & 0.89 \\
\hline
\end{tabular}

$\mathrm{AC}=$ amylose content, $*$ and ${ }^{* * *}$ significant different at $\mathrm{P}<0.05$ and $\mathrm{P}<0.001$ probability levels respectively, (a) relative importance of GCA and SCA according to Baker (1978); (b) Broad sense heritability, (c) Narrow sense heritability and $\delta 2 \mathrm{~g}$, and $\delta 2 \mathrm{~s}$, are the respective GCA, and SCA, components; $\delta 2 \mathrm{e}$ is the error component averaged over three replications

$(\mathrm{P}<0.001)$ among parents for GCA and crosses $(\mathrm{P}<0.5)$ for SCA. The significance of GCA and SCA indicates that both additive and nonadditive gene effects are important in determining AC (Dabholkar, 1992). However, the variance component for GCA ( $22 \mathrm{GCA})$ was greater than the variance component for SCA ( $\delta 2$ SCA ); implying that the inheritance of amylose content is more conditioned by the additive gene effects than the dominance gene effects. Similar results were reported by Sharif et al. (2010) on Indical rice. Baker (1978) reported that the closer the ratio of GCA: SCA to unity, the greater the predictability based on GCA alone. The GCA:SCA in this study was 0.94 , implying that the performance of a single cross progeny can be predicated fairly accurately, based on the GCA of its parent in this study. The broad sense heritability was 0.96 , indicating that $96 \%$ of the observable amylose content was due to genetic effect. The narrow sense heritability of 0.89 indicates that early selection for AC could give a good response; suggesting that the efficiency of rice breeding programmes for cooking quality trait based on would be possible through selection AC percentage.

\section{ACKNOWLEDGEMENT}

Intra-ACP CASS mobility scholarship supported the study and National Resources Research Institute provided the materials and facilities to carry out the research.

\section{REFERENCES}

Baker, R. J. 1978. Issues in Diallel Analysis. Crop Science 18:533-536.

Bao, J., Xi. Kong, J. Xie and Linjuan, X. 2004. Analysis of genotypic and environmental effects on rice starch; apparent amylose content, pasting viscosity, and gel texture. Agricultural and Food Chemistry 52(19): 6010-6016. https://doi.org/10.1021/ jf049234i 
Bernardo, R. 2001. What if we knew all the genes for a quantitative trait in hybrid crops? Crop Science 41(1):1-4.

Candia A.O. T. 2013. Effect of paddy drying depth using open-sun drying on drying time and mill recovery of Kasio variety in eastern Uganda. Uganda Journal of Agricultural Sciences 37-47.

Champagne, E.T., Bett-Garber, K.L., McClung, A.M. and Bergman, C. 2004. Sensory characteristics of diverse rice cultivars as influenced by genetic and environmental factors. Cereal Chemistry 81(2):237-243

Dabholkar, A.R. 1992. Element of biometrical Genetic. New Delhi, India: Ashok Kumar Milttal.

Efferson, J.N. 1985. Rice quality in world market. In: Rice grain quality and marketing. pp. 1-15.

Fasahat, P., Muhammad, K., Abdullah, A. and Rahman, A. 2014. Genotype x environment assessment for grain quality traits in rice. COmmunications in Biomert and Crop Science 9(2):71-82.

Graham, R. 2002. IRRI discussion paper series. In: A proposal for IRRI to establish a grain quality and nurition research center p. 15.

Grifing, B. 1956. Concept of general and specific combining ability in relation to diallel crossing system. Australian Journal of Biological Sciences 9:4163-4193.

Kuo, Y.C., Bill, D.W. and James W. S. 1996. Genetic study on molled rice amylose

Jing, Q., Spiertz, J.H.J,Hengsdijk, H. van Keulen, W. and Cao, T.D. 2010. Adaption and performance of rice genotype in tropical and sub-tropical environments. Journal of Life Sciences 57:149-157. https://doi.org/ 10.1007/s00122-006-0218-1

Juliano, B.O. 1971. A simplified assay for milled rice amylose. Cereal Science Today 16: 334-338.

Kanchana, S., Bharathi, S. L., Ilamaran, M., and Singaravadivel, K. 2012. Physical quality of selected rice varieties, Department of Food Science and Nutrition,
Home Science College and Indian Institute of Crop Processing Technology, Thanjavur, Tamil Nadu, India 8(5):468472. https://doi.org/10.5829/idosi.wjas. 2012.8.5.1666

Koutroubasa, S.D., Mazzinib, F., Ponsc, B. and Ntanosd, D.A. 2004. Grain quality variation and relationship with the morphological traits in rice (Oryza sativa L.) genetic resource in Europe. Field Crop Research 86:559-568.

Lamo, J., Tongoona, P., Okori, P., Moussa, S., Mande, S. and Onaga, G. 2017. Upland rice breeding in Uganda: Initiatives. In: Rice. Elsevier Ltd. https://doi.org/10.1016/ j.foodchem.2014.04.011. 33pp.

Lanceras,J.C., Zue-Liu Huang, Onanong Naivikul, Vinitchan Ruanjaichon, and Somvong Tragoonrung, A.V. 2000. Mapping of genes for cooking and eating qualities in Thai. DNA Research 7:93-101.

Lee, Y.E. 1987. Physicochemical factors affecting cooking and eating quality of nonwaxy rice, 9270.

MAAIF. 2012. Uganda national rice development strategy. Kampala, Uganda.

Paule, C.M., Gomez, K.A, Juliano, B.O. and Cffman, W.R. 1977. Variability in amylose content in rice philipines.

Peter, R.J., Beachall, H.M. and Chuaviroj, M. 1964. An improved rice hrbridization technique. Alliance of Crop, Soil and Environmental Sciences 8:24-31.

Resurreccion, A.P., Hara, T., Juliano, B.O., and Yoshida, S. 1977. Effect of temperature during ripening on grain quality of rice. Soil Science and Plant Nutrition 23(1):109-112. https://doi.org/10.1080/ 00380768.1977 .10433027

Roy, S., Banerjee, A., Senapati, B.K. and Sarkar, G. 2012. Comparative analysis of agro-morphology, grain quality and aroma traits of traditional and Basmati-type genotypes of rice (Oryza sativa L.). Plant Breeding 131(4):486-492.

Sharifi, P., Dehghani, H., Moumeni, A. and Mohammad, M. 2010. Genetic main effect and genotype environment interaction for 
cooking quality traits in a diallel set of Indica rice (Oryza sativa L.) varieties. Crop and Pasture Science 61:475-482.

Sharifi, P., Dehghani, H., Ali, M. and Mohammad, M. 2009. Genetic and genotype $\mathrm{x}$ environment interaction effects for appearance quality of rice. Agricultural Sciences in China 8(8):891-901. https:// doi.org/10.1016/S1671-2927(08)60293-X

Singh, N., Kaur, L. and Sodhi, N.S. 2005. Physicochemical, cooking and textural properties of milled rice from different Indian rice cultivars. Food Chemistry 89: 253-259.

Singh, R.K. and Chaudhary, B. 2007. Biometrical method in quantitative genetic analysis. New Delhi -Ludihana: Kalyani, India.

Tan, Y.F, Xing, Y.Z., Li, J.X., Yu, S.B., Xu, C.G. and Qifa, Z. 2000. Genetic bases of appearance quality of rice grains in Shanyou 63 , an elite rice hybrid. Theory and Applied Genetic 101:823-829.

Vijay Kumar. 2015. Variability and correlation studies for grain physicochemical characteristics of rice (Oyrza sativa L.). The Bioscan 10(2):917-922.

Zheng-xun, J.I.N., Chun-rong, Q.I.A.N., Jing, Y.A.N.G., Hai-ying, L. I. U. and Xue-yong, J.I.N. 2005. Related to starch synthesis and grain quality of rice. Rice Science 12(4): 261-266. 